\title{
Hydraulic potential of the Lower Vistula (Poland)
}

\author{
Michal Szydlowski ${ }^{1,}$, Romuald Szymkiewicz ${ }^{1}$, Dariusz Gasiorowski ${ }^{1}$, Jakub Hakiel ${ }^{1}$, and \\ Piotr Zima ${ }^{1}$ \\ ${ }^{1}$ Gdansk University of Technology, Faculty of Civil and Environmental Engineering (GUT), Gabriela \\ Narutowicza 11/12 80-233 Gdansk, Poland
}

\begin{abstract}
The Vistula is the largest river in Poland. Lower Vistula (part of the river discussed in this paper) is almost four hundred kilometers long river section extending from the tributary Narew to the outflow to the Baltic Sea. In the $17^{\text {th }}$ century the Vistula was the most navigable river in Europe. After partitioning of Poland the Vistula lost its significance. Now the Lower Vistula should provide a navigation connection to the Europe forming water routes E70 and E40. However it does not meet the criteria required for the international waterways. Moreover, the river has a quite large hydro-energy potential. There have been many plans for the development of the Lower Vistula River so far. Unfortunately none of them has been implemented. In this paper, the authors would like to present their own arguments to reactivate the Lower Vistula Cascade (LVC) project. In order to analyse the LVC idea and Lower Vistula hydraulic potential, a numerical hydraulic model of the Lower Vistula was developed at the Department of Hydraulic Engineering of Gdansk University of Technology. Various aspects of the LVC concept, such a potential inland waterways, hydropower, flood control and water retention, are discussed in the article.
\end{abstract}

\section{Introduction}

The Vistula River is one of great European rivers. Its length is $1047 \mathrm{~km}$. Its river bed is totally located inside of the Polish borders. Similarly, major part (ca $87 \%$ ) of its total catchment area equal to $194000 \mathrm{~km}^{2}$ belongs to Poland. The average discharge in its mouth to Baltic Sea is estimated as equal to $1080 \mathrm{~m}^{3} \mathrm{~s}^{-1}$, whereas the total annual outflow of waters coming from the atmospheric precipitations and introduced by Vistula to sea is approximately equal to $34 \mathrm{~km}^{3}$.

Insignificant degree of making use of the Vistula River potential makes essential difference comparing with others great European rivers. In current Polish economy the Vistula River practically does not take any part. Years ago, in XV, XVI and XVII century, the Vistula River played essential role. In the Middle centuries it was one of the most important European waterways. Unfortunately, many different (political, economical and geophysical) factors and processes acting for long times caused that currently there is a great difference between the Vistula River and other European rivers. For many reasons the most interesting for economical use of the Vistula River is its Lower part of length equal about $400 \mathrm{~km}$, called the Lower Vistula. It is considered from Warsaw cross section to the Gulf of

\footnotetext{
* Corresponding author: michal.szydlowski@,wilis.pg.edu.pl
} 
Gdansk. After the end of the $2^{\text {nd }}$ World War there was undertaken many times idea of exploitation of the Lower Vistula River. This idea was dealing with construction of a cascade of dams and reservoirs. The only effect of undertaken project of a cascade is the Wloclawek barrage finished in 1970 and which is the only its element still working alone. Recently the Polish authorities made a decision on the second dam which will be located downstream the Wloclawek one.

At the present time the question of economic use of the lower Vistula River became particularly important because intensively developed the Port of Gdansk, located at the mouth of Vistula River, will soon need additional connection in the form of waterway with the center of Poland. On the other hand, while discussion dealing with the Vistula River, usually only general opinions and arguments are presented. It seems to the authors that it would be better if such discussions were supported at least by the results of basic hydraulic analysis. To this order, the authors would like to present their own (hydraulic) arguments to reactivate the barrage cascade project. Various aspects of the concept, such creation of the potential inland waterway, hydropower, flood control and water retention, are discussed in the article.

\section{Lower Vistula Cascade model}

The Lower Vistula includes the $391 \mathrm{~km}$ river section (Fig. 1) from the mouth of Narew (550.5 $\mathrm{km})$ to the Balic Sea $(941.5 \mathrm{~km})$. In the analysed section the largest right hand side tributaries are: Narew $\left(328 \mathrm{~m}^{3} \mathrm{~s}^{-1}\right)$, Drweca $\left(45 \mathrm{~m}^{3} \mathrm{~s}^{-1}\right)$, and Osa $\left(7 \mathrm{~m}^{3} \mathrm{~s}^{-1}\right)$. The largest left-hand tributaries are: Bzura $\left(23 \mathrm{~m}^{3} \mathrm{~s}^{-1}\right)$, Brda $\left(22 \mathrm{~m}^{3} \mathrm{~s}^{-1}\right)$, Wda $\left(11 \mathrm{~m}^{3} \mathrm{~s}^{-1}\right)$ and Wierzyca $\left(8 \mathrm{~m}^{3} \mathrm{~s}^{-1}\right)$. The average flow rate of the Vistula River at outflow cross section is $1080 \mathrm{~m}^{3} \mathrm{~s}^{-1}$.

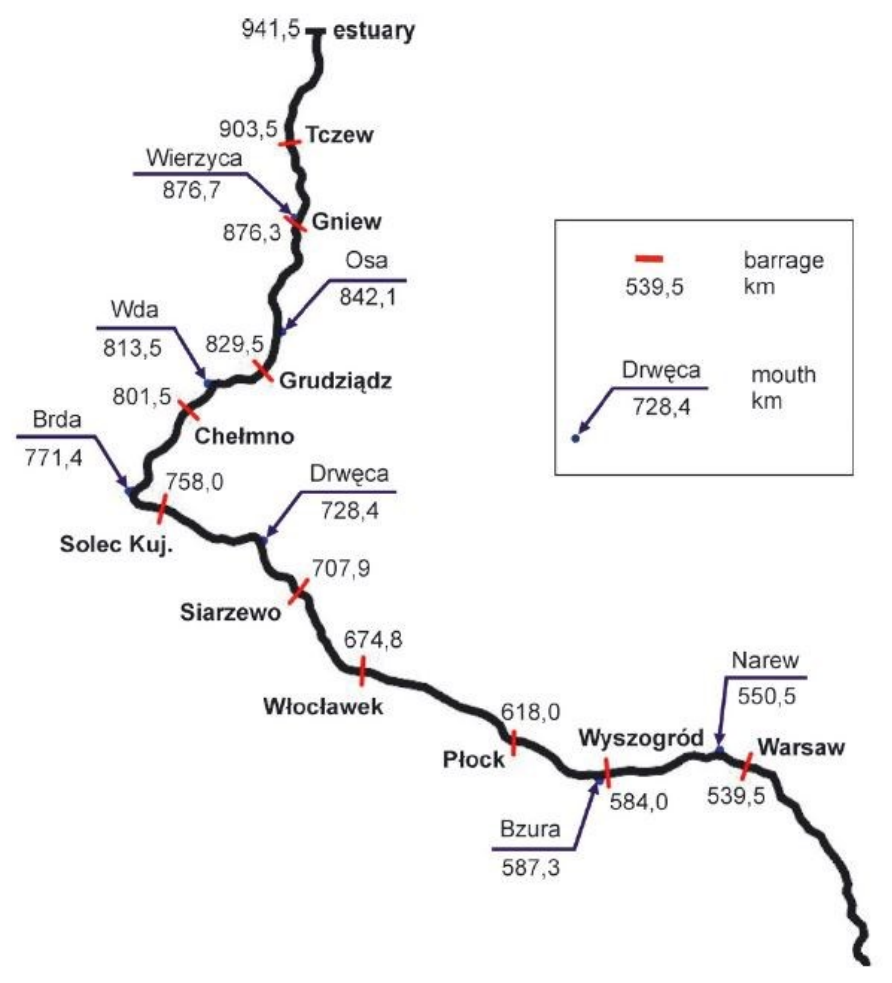

Fig. 1. Lower Vistula system with LVC barrages concept 
In the 1950s a concept was developed for the Lower Vistula of a cascade of barrages. The Lower Vistula Cascade (LVC) at the section from Wyszogrod to Tczew was originally designed as a system of eight barrages, further expanded with the Grudziadz barrage and the Warsaw barrage (Fig. 1). The LVC concept had changed over the years, and the changes focused mainly on the number of barrages and their locations, and the damming levels adopted for them. A detailed and historical account of the LVC project's various modifications in 1957-2009 can be found in [1]. Out of the whole cascade system only one barrage was developed in Wloclawek, with construction completed in 1970.

An initiative to reactivate the project of another LVC barrage has been taken by Energa SA (electric energy operator) and Gdansk University of Technology (GUT) [2]. In order to analyse the proposed LVC impact on flow conditions, a hydraulic model of the Lower Vistula was developed at the Department of Hydraulic Engineering of GUT. The LVC river flow simulations were determined on the basis of hydraulic calculations made using the software package of HEC-RAS (Hydrologic Engineering Centre - River Analysis System) [3]. The model of the Vistula River was developed based on details of the river bed geometry (325 river cross-sections), roughness coefficients of individual design sections, and tributaries inflows. In addition, the model has included the existing hydro engineering facilities (bridges and Wloclawek barrage) and the proposed development of LVC barrages (Tab. 1). For the purpose of this analysis it was assumed that the cascade is made up of nine barrages located at the section from Wyszogrod $(584.0 \mathrm{~km})$ to Tczew $(903.5 \mathrm{~km})$, including the existing barrage in Wloclawek (Fig. 1), and the Warsaw barrage $(539.5 \mathrm{~km})$. It was also assumed that the reservoirs will be bounded with side dams, natural high banks of the valley and the current line of levees. In Table 1 basic details of LVC barrages chosen for hydraulic calculations are listed. The calculations were made for steady and unsteady flows.

Table 1. Barrages parameters in the adopted LVC concept.

\begin{tabular}{|c|c|c|c|c|c|c|}
\hline \multirow{2}{*}{ Dam } & $\begin{array}{c}\text { River } \\
\text { cross- } \\
\text { section }\end{array}$ & $\begin{array}{c}\text { Flow } \\
\text { rate }\end{array}$ & $\begin{array}{c}\text { Normal } \\
\text { water } \\
\text { stage }\end{array}$ & $\begin{array}{c}\text { Max } \\
\text { water } \\
\text { stage }\end{array}$ & $\begin{array}{c}\text { Min } \\
\text { water } \\
\text { stage }\end{array}$ & $\begin{array}{c}\text { Weir } \\
\text { crest }\end{array}$ \\
\cline { 2 - 7 }$(\mathrm{km})$ & $\left(\mathrm{m}^{3} \mathrm{~s}^{-1}\right)$ & \multicolumn{4}{|c|}{ (m a.s.1.) } \\
\hline Tczew & 903.5 & 1046 & 11.0 & 12.5 & 10.5 & 3.2 \\
\hline Gniew & 876.3 & 1037 & 18.5 & 20.0 & 18.0 & 10.7 \\
\hline Grudziadz & 829.5 & 1027 & 25.5 & 27.0 & 25.0 & 17.7 \\
\hline Chelmno & 801.5 & 1013 & 32.5 & 34.0 & 32.0 & 24.7 \\
\hline Solec Kuj. & 758.0 & 986 & 41.0 & 42.5 & 40.5 & 33.2 \\
\hline Siarzewo & 707.9 & 914 & 46.0 & 46.5 & 45.3 & 38.2 \\
\hline Wloclawek & 674.8 & 911 & 57.3 & 58.5 & 56.5 & 50.5 \\
\hline Plock & 618.0 & 942 & 64.0 & 65.5 & 63.5 & 56.2 \\
\hline Wyszogrod & 584.0 & 886 & 70.5 & 72.0 & 70.0 & 62.7 \\
\hline Warsaw & 539.5 & 549 & 81.0 & 82.5 & 80.5 & 73.2 \\
\hline
\end{tabular}

In addition to barrage cascade, the bridges crossings the river were taken into account in the Lower Vistula model. There are 19 structures like road, railway and road-rail bridges from $\mathrm{km} 540$ to $\mathrm{km} 941$ of this river segment.

Characteristic flow rates, necessary to calculate flow parameters in steady flow conditions, were estimated at gauge cross-sections, as well as at cross-sections corresponding 
to the location of designed cascade dams. The values of hydrologic flow rates are presented in Table 2.

Table 2. Characteristic mean annual flow rates along Lower Vistula.

\begin{tabular}{|c|c|c|c|}
\hline $\begin{array}{c}\text { Cross- } \\
\text { section } \\
(\mathrm{km})\end{array}$ & Location & $\begin{array}{c}\text { Mean flow } \\
\text { rate }\left(\mathrm{m}^{3} \mathrm{~s}^{-1}\right)\end{array}$ & $\begin{array}{c}\text { Low flow } \\
\text { rate }\left(\mathrm{m}^{3} \mathrm{~s}^{-1}\right)\end{array}$ \\
\hline 504.1 & Warsaw & 549 & 233 \\
\hline 551.5 & Modlin & 872 & 339 \\
\hline 586.9 & Wyszogrod & 886 & 340 \\
\hline 606.5 & Kepa Polska & 948 & 340 \\
\hline 632.4 & Plock & 942 & 333 \\
\hline 679.4 & Wloclawek & 911 & 293 \\
\hline 707.9 & Siarzewo & 914 & 313 \\
\hline 734.7 & Torun & 983 & 356 \\
\hline 762.0 & Solec Kuj. & 986 & 358 \\
\hline 806.8 & Chelmno & 1013 & 382 \\
\hline 835.0 & Grudziadz & 1027 & 394 \\
\hline 876.3 & Gniew & 1037 & 404 \\
\hline 908.6 & Tczew & 1046 & 411 \\
\hline 938.7 & Swibno & 1080 & 411 \\
\hline
\end{tabular}

The shape of the hypothetical flood wave used in the unsteady flow analysis was determined using the Warsaw University of Technology method [4]. The obtained hypothetical flood waves, with peak values equal to $5097,7090,9794 \mathrm{~m}^{3} \mathrm{~s}^{-1}$ for probabilities of exceedance 10 , $1,0.2 \%$, respectively, and duration about two months, were used in the hydrodynamic (unsteady) model as the upper boundary condition.

\section{Hydraulic calculations}

Hydraulic calculations were performed first to determine flow conditions for two variants of the development of the Lower Vistula. The calculations for the current state were made to determine the shape of the water table profiles for mean flow rates. In the calculations, the Wloclawek dam was taken into account, where the normal water stage was imposed. Then, in order to determine the impact of the adopted LVC development on the flow conditions, simulations of water flow with the existing (bridge structures and Wloclawek barrage) as well as the assumed hydro engineering structures have been performed. The calculated water stage profiles for mean annual flow rate are shown in Figure 2.

For almost 50 years, Wloclawek has been operating as a single dam. Such a state of work, inconsistent with the assumptions adopted in the original project, has caused many unfavorable processes, such as intensive erosion of the bottom, which degrades the river bed downstream the barrage and concrete elements of the dam. Negative effects of the lack of the dam cascade are well visible on the longitudinal profile of the river, shown in Figure 2. Such a situation and previously mentioned processes have reduced the safety of the entire facility, and the only way to permanently ensure structure safety was to consider the construction of a downstream dam raising water table to $46.0 \mathrm{~m}$ above sea level. Such a solution (Siarzewo barrage) was designed and accepted by Polish government last year (2017). As in the case of Wloclawek dam, the safety of the entire LVC depends on the hydraulic support of each of the dam. As shown by hydraulic calculations (Fig. 2), the LVC parameters assumed for analysis (Tab. 2) guarantee hydraulic support of dams, which will ensure safe operating conditions for individual structures. 


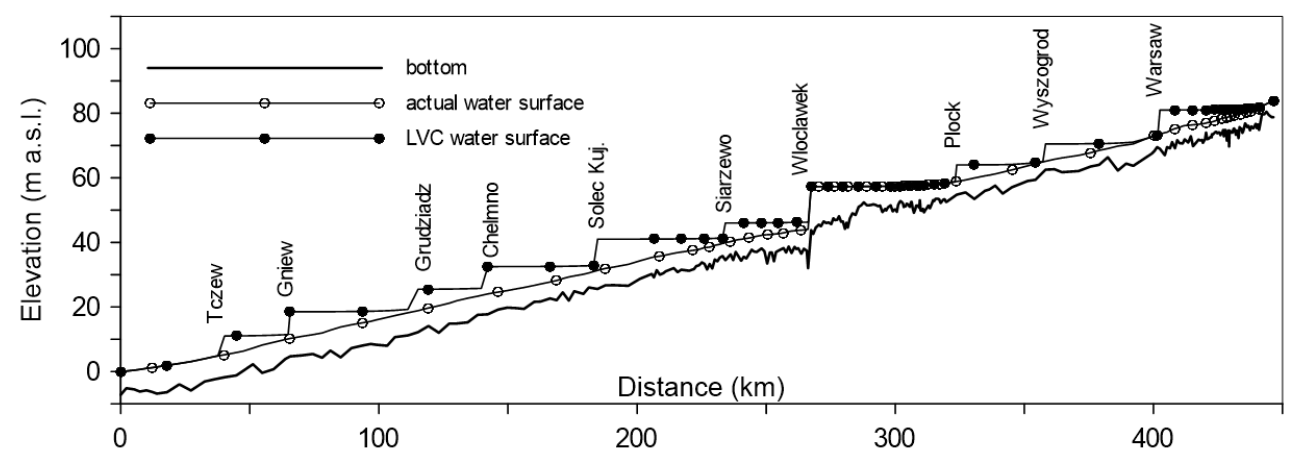

Fig. 2. Calculated Lower Vistula water stages in present state and with LVC concept

An important issue related to the hydraulics of the Lower Vistula is the development of inland water transport proposed by the European Union. In Poland, it is planned to build three international waterways - E30 connecting the Baltic Sea with the Danube in Bratislava, E40 connecting the Baltic Sea with the Black Sea and E70 constituting the East-West European communication route connecting Klaipeda with Antwerp. The Vistula River within the tasks of the European Union is qualified to the waterway E70. As part of the development of the Polish section of this waterway, it is required to maintain the navigable route of international class. It should also be noted that the E40 and E70 waterways have a common section on the Vistula from Gdansk to Bydgoszcz. A waterway with the status of an international water route must meet some technical requirements. First, the minimum transit depth for the waterway of international class is $2.80 \mathrm{~m}$. To test the fulfillment of this condition on the analysed section of the river, the results of calculations of the average depth in the Lower Vistula River bed for the present state with the minimum transit depth were compared, as shown in Figure 3.

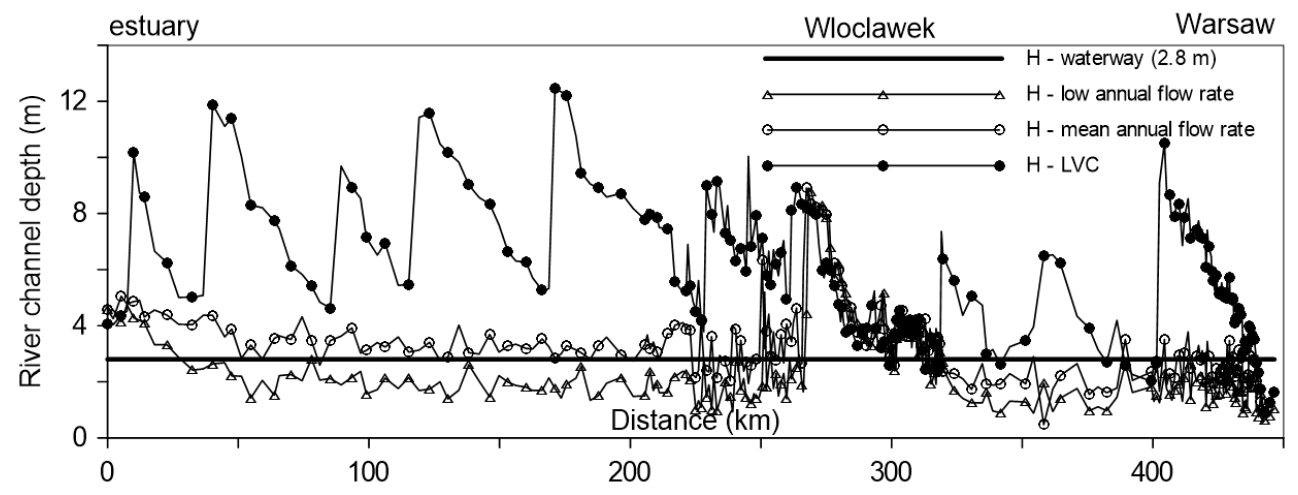

Fig. 3. Calculated water depth in present river state for low and mean annual flow rates and with adapted LVC concept

Depth calculations were made for two characteristic flow rates - the mean and low annual flows. As it can be seen for mean flow rates, the depth in the channel is greater than the minimum transit depth on the sections downstream and along the Wloclawek reservoir. In the section upstream Wloclawek reservoir, the depths are too small to provide the desired international waterway class. It should also be mentioned that the duration of the mean annual flows on the Vistula River is only slightly over 100 days a year. In the case of low flows 
occurring in the river, the depths exceed the value necessary for the international waterway only on the section of the Wloclawek reservoir and in the region of the estuary to the sea.

The outdated data show that the minimum transit depth for a waterway with an international class, with mean and low water levels cannot be ensured otherwise than by cascading the river. In connection with the above, depth calculations for the LVC concept were made and again confronted with the necessary transit depth (Fig. 3). The calculations confirmed that cascading of the river guarantees the creation of a waterway with parameters required for the international class. Only the locally calculated depth on the section near Warsaw is less than $2.8 \mathrm{~m}$, which means that in the case of cascade construction, local dredging works will be needed, related to the appropriate shaping of the bottom.

The waterway classification also includes distance between bridge structure and water table. The minimum distance for the international class is $5.25 \mathrm{~m}$. Analysis of calculated water table profiles for adopted LVC shows that this condition will not be met by three structures: a new motorway bridge in Grudziadz ( $\mathrm{km} \mathrm{827.82)}$ with a distance of $3.91 \mathrm{~m}$, bridge in Bydgoszcz $(\mathrm{km}$ 774.86) with a distance of $3.45 \mathrm{~m}$ and a bridge Pilsudskiego in Torun ( $\mathrm{km} \mathrm{725.2)} \mathrm{with} \mathrm{a} \mathrm{distance} \mathrm{of} 0.21 \mathrm{~m}$. Meeting the international class requirements in relation to the distance under these bridges will require reconstruction of these facilities (bridges in Torun and Bydgoszcz) or changing the location of the dam near Grudziadz.

In order to determine the LVC hydro power potential, for each barrage the maximum and minimum output powers were determined, as well as average annual energy output. Plant output power for each power plant were determined after the following formula:

$$
P=9.81 \cdot \eta \cdot Q_{e} \cdot H_{n}
$$

where $P$ - output power (kW), $\eta$ - overall plant efficiency (-), $Q_{\mathrm{e}}$ - discharge through plant $\left(\mathrm{m}^{3} \mathrm{~s}^{-1}\right), H_{\mathrm{n}}$ - net water head $(\mathrm{m})$.

Table 3. LVC power and annual energy outputs for various maximum flows through plant $Q_{\mathrm{e}, \max }$.

\begin{tabular}{|c|c|c|c|}
\hline $\begin{array}{c}\text { Flow through } \\
\text { power plant } \\
Q_{\mathrm{e}, \max }\left(\mathrm{m}^{3} \mathrm{~s}^{-1}\right)\end{array}$ & $\begin{array}{c}\text { Min. power } \\
P_{\min }(\mathrm{MW})\end{array}$ & $\begin{array}{c}\text { Max. power } \\
P_{\max }(\mathrm{MW})\end{array}$ & $\begin{array}{c}\text { Energy output } \\
E(\mathrm{GWh})\end{array}$ \\
\hline 900 & 152.4 & 507.1 & 3428.4 \\
\hline 1200 & 152.4 & 633.6 & 3840.2 \\
\hline 1500 & 152.4 & 757.4 & 4083.2 \\
\hline 1800 & 152.4 & 857.4 & 4221.1 \\
\hline
\end{tabular}

The details of LVC hydropower potential calculation were presented in [5]. The aggregated power and energy outputs of LVC system including all the barrages of LVC for the analysed flows through the power plants are presented in Table 3. The largest total maximum power of $857.4 \mathrm{MW}$ can be achieved with the plants discharge capacity of $1800 \mathrm{~m}^{3} \mathrm{~s}^{-1}$. The respective average annual energy output of all LVC barrages is $4221.1 \mathrm{GWh}$.

The construction of LVC, in the variant presented in this paper, means the creation of nine new retention reservoirs, which combined with the proper control of water stages during the passage of flood waves will give a significant effect of reducing the culmination of the wave and thus reduce the flood risk in the Vistula valley. This conclusion was confirmed by the results of modeling steady flows and the transformation of flood waves. It should be emphasized that the construction of a full LVC, under the assumptions adopted at work, will result in a flood retention with a value of the order of 520 million $\mathrm{m}^{3}$. The total flood retention in dynamic conditions of flood wave transitions was estimated at about 710 million $\mathrm{m}^{3}$. In relation to the total volumes of the largest flood waves counted in billion $\mathrm{m}^{3}$, this is not a value guaranteeing the total retention of each wave. However, calculated reduction of the 
culmination of flood waves over $1000 \mathrm{~m}^{3} \mathrm{~s}^{-1}$ can ensure a significant increase in the degree of protection of the valley against floods.

\section{Hydraulic effects of LVC construction}

\subsection{Safety of Wloclawek dam}

The Wloclawek dam built in 1962-1970 functions independently as the only element of the planned cascade of the Lower Vistula. This is a bizarre situation unheard of in hydraulic engineering practice. Its consequence was the launch of intensive erosion processes downstream the Wloclawek dam causing systematic lowering of the Vistula bottom. This decrease currently covers a relatively long section of the river and ranges from over $3.50 \mathrm{~m}$ just downstream the Wloclawek dam to about $0.50 \mathrm{~m}$ in Torun, distant by $60 \mathrm{~km}$. Stabilization of the situation in the Vistula channel and safety of dam can only be achieved by constructing a barrage downstream Wloclawek dam, adding the next step of the cascade.

\subsection{Protection against flooding of the Lower Vistula valley}

Construction of the cascade is the creation of additional retention reservoirs. The calculations show that even if their capacities are much smaller than the capacity of the Wloclawek reservoir, the combined effect of the entire cascade with proper control of the flow during the flood wave transition will give a significant effect of reducing the culmination of the wave and thus reduce the risk of the Vistula River valley flooding. In addition, the existence of reservoirs will eliminate currently the most probable cause of possible floods for which ice jams are considered.

\subsection{Lower Vistula as an inland waterway}

The Lower Vistula is part of the E40 waterway, which should connect the Black Sea with the Baltic Sea and the E70 waterway connecting the North Sea with the Baltic Sea. Their technical parameters should meet the requirements set for the waterway of international category. In order to meet the requirements for depth, it is necessary to raise the river water stage. The simulations performed showed that with low flow rates, the Lower Vistula will never be an international waterway and with mean flow rates it will only meet them for a short period of the year, while the cascade will provide the required parameters in a permanent way. The calculations show that the minimum distance between the water table and the bottom of existing bridges will require correcting the location of some cascade dams, as well as raising some of the bridge structures.

\subsection{Lower Vistula as a source of electricity}

With the construction of dams, it is always possible to use the created difference of levels of upstream and downstream water stages for possible production of electricity. In this case, the idea of building a hydroelectric power plant seems obvious. Taking into account the Wloclawek power plant (capacity $160 \mathrm{MW}$ ), its importance in the national energy system and economic effects, one should also expect significant benefits resulting from the production of electricity on other dams of the cascade. This justified assumption is confirmed by the analyses made, which show that depending on the hydrological conditions prevailing, the total installed capacity at the cascade stages can range from more than $500 \mathrm{MW}$ to almost $860 \mathrm{MW}$, enabling energy production over $4200 \mathrm{GWh}$ per year. 


\subsection{Reservoir retention and water supply}

The construction of the LVC will allow the retention of water. Assuming that the planned reservoirs are located within existing valleys, their total capacity will amount to approximately 1.2 billion $\mathrm{m}^{3}$. Referring this value to the total reservoir retention in Poland of 3.7 billion $\mathrm{m}^{3}$, it can be seen that the construction of the cascade will significantly improve the water retention. It is worth adding that LVC will allow to meet the water needs of adjacent regions with the lowest rainfall in Poland. The demand for agriculture and industry water can be satisfied by using water retained in the cascade of reservoirs.

\section{Conclusions}

The results of analysis allow to formulate the following general conclusion. Comprehensive use of various possibilities of the Lower Vistula is possible only due to the construction of the cascade of barrages, in which the dams are located in series along the river. The LVC is the only technical solution that on the one hand enables comprehensive use of the potential of this section of the river and on the other hand limits the threats it generates.

In particular, the cascade of the Lower Vistula River will allow 1) to produce remarkable quantity of hydro energy because more than $50 \%$ (ca $800 \mathrm{MW}$ ) of the hydro energy potential in Poland is represented by the Lower Vistula; 2) to develop the international European waterways E40 and E70 connecting the Polish maritime ports with the center of Poland and with the neighboring countries; 3 ) to increase remarkably the total capacity of required retention in Poland; 4) to increase flood protection in the river valley; and finally 5) to increase the water supplying in the regions for agriculture and industry which currently suffer for severe shortage of water (average annual precipitation about $450 \mathrm{~mm}$ ).

\section{Impact of the research on the policy decisions}

The results of analysis and conclusions presented by the authors were disseminated in Poland. In the years 2014-2017 they were presented to the local and national authorities as part of the seminars regarding the reactivation of inland waterways in Poland. It seems that they caused some positive effects on the policy issues concerning the strategy for the Lower Vistula, since recently several important decisions dealing with the development of the Port of Gdansk and the Lower Vistula River have been made by the Polish Authorities.

\section{References}

1. I. Ankiersztejn Acta Energetica 3/16 70 (2013)

2. M. Szydlowski D. Gasiorowski J. Hakiel P. Zima R. Szymkiewicz Inzynieria Morska i Geotechnika 5420 (2014) (in polish)

3. G. W. Brunner HEC-RAS 5.0 River Analysis System, Hydraulic Reference Manual (US Army Corps of Engineers 2015)

4. K. Banasik (Ed.) A methodology for calculating flows and maximum flows with specified maximum exceedance probability for controlled and uncontrolled catchments, and for identifying rainfall to runoff transition models (Association of Polish Hydrologists 2009)

5. M. Szydlowski D. Gasiorowski R. Szymkiewicz P. Zima J. Hakiel Acta Energetica $\mathbf{1 / 2 2} 18$ (2015) 